\title{
Initiation Sensitivity of HNS I Pellets BY HNS II MDF AS A FUNCTIION OF Pellet Density and MdF Loading
}

\author{
L. D. Hanes
}

DEVELOPMENT DIVISION

MASTER

APRIL 1976

(P.O. No. 03-2697)

INTERIM REPORT NO. I
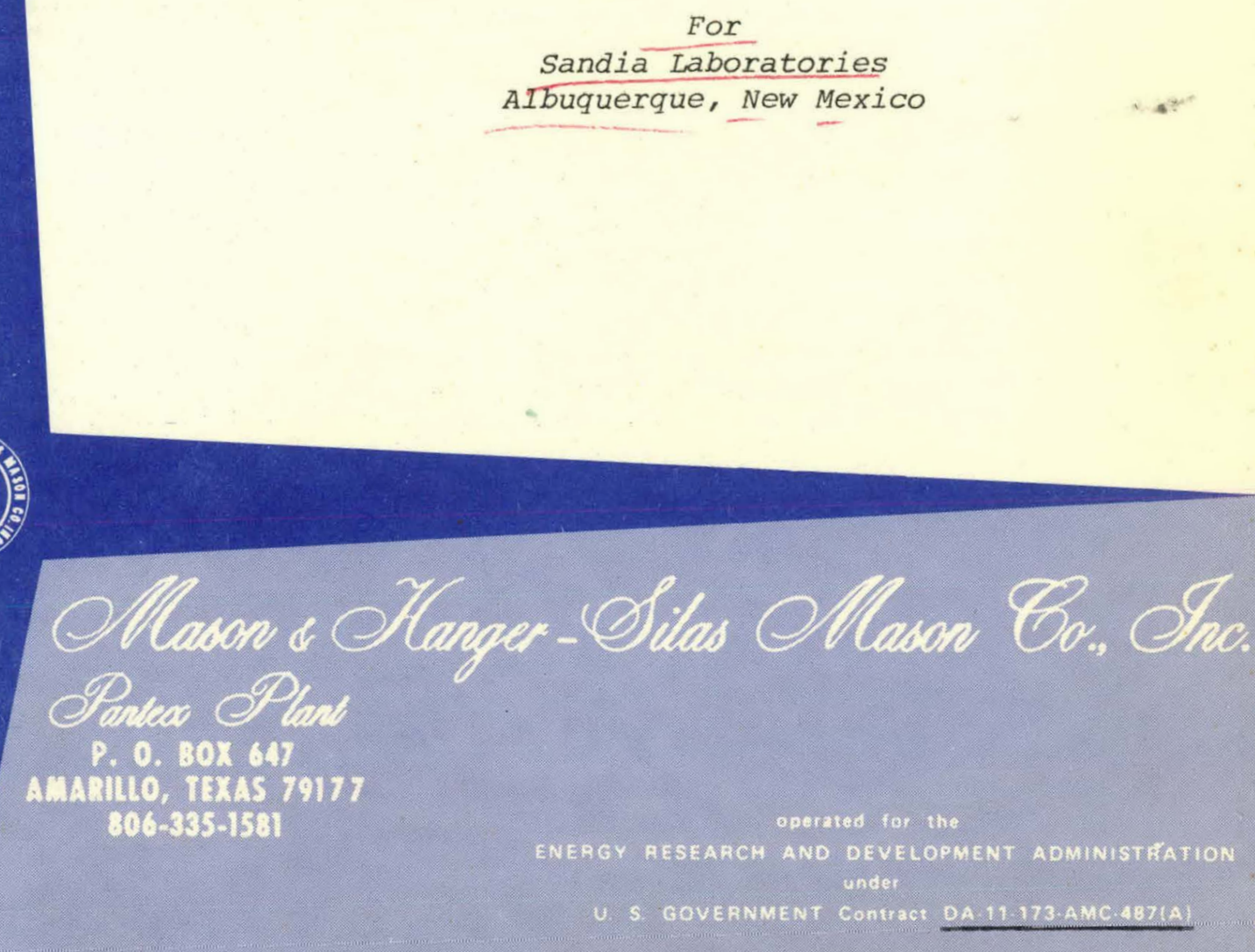


\section{DISCLAIMER}

This report was prepared as an account of work sponsored by an agency of the United States Government. Neither the United States Government nor any agency Thereof, nor any of their employees, makes any warranty, express or implied, or assumes any legal liability or responsibility for the accuracy, completeness, or usefulness of any information, apparatus, product, or process disclosed, or represents that its use would not infringe privately owned rights. Reference herein to any specific commercial product, process, or service by trade name, trademark, manufacturer, or otherwise does not necessarily constitute or imply its endorsement, recommendation, or favoring by the United States Government or any agency thereof. The views and opinions of authors expressed herein do not necessarily state or reflect those of the United States Government or any agency thereof. 


\section{DISCLAIMER}

Portions of this document may be illegible in electronic image products. Images are produced from the best available original document. 


\section{NOTICE}

This report was prepared as an account of work sponsored by the United States Government. Neither the United States nor the United States Energy Research and Development Administration, nor their employees, nor any of their contractors, subcontractors, or their employees, makes any warranty, express or implied, or assumes any legal liability or responsibility for the accuracy, completeness or usefulness of any information, apparatus, product or prnress disclosed, or represents that its use would not infringe privately-owned rights. 


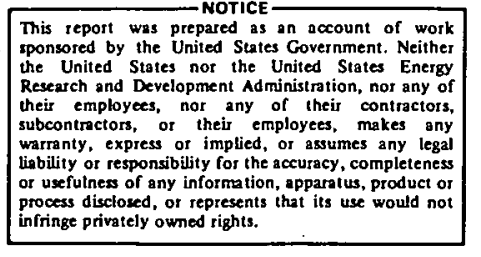

\section{Initiation Sensitivity of HNS I Pellets by. HNS II MDF as a Function of Pellet Density and MDF Loading}

L. D. Hanes

DEVELOPMENT - DIVISTION

April 1976

P. O. No. 03-2697 


\section{ABSTRACT}

Excess transit time of a relatively large diameter HNS I acceptor pellet when ignited by an HNS II MDF donor is being investigated as a function of both pellet density and MDF core loading.

\section{DISCUSSION}

The purpose of the project is to establish the excess transit time of a detonation wave for an acceptor pellet which is initiated by MDF. There are two parts: one, to define at a fixed pellet density the relationship between excess transit time and MDF size, and two, to define for a given MDF size the relationship between excess transit time and acceptor pellet density.

Two $15 \mathrm{~m}$ lengths of MDF which were manufactured by Ensign-Bickford (E-B) and Explosive Technology (ET) were supplied to Pantex by SLA for use in the excess transit time study. Samples of each MDF were drawn in a pilot operation to determine several pertinent properties, which are shown in Table. I. The outside diameters 1 isted include all die sizes available at Pantex in the range of interest. The pellets were pressed from Pantex-synthesized hịg-purity HNS I(1), Lot. PX-11.

In part one, the two MDF samples are to be drawn to smaller sizes and tested with acceptor pellets of $1.60 \mathrm{Mg} / \mathrm{m}^{3}$ density. The smallest size of MDF tested is to be below the critical size necessary for an initiation reliability of $50 \%$. In the second part, the two MDF samples are to be tested in their original form as received from the vendor with acceptor pellet densities of $1.65,1.60,1.50$ and $1.40 \mathrm{Mg} / \mathrm{m}^{3}$. No MDF will be hydraulically compacted.

\section{EXPERIMENTAL TECHNIQUE AND RESULTS}

The detonation electric effect technique(2) is utilized to measure detonation front arrival times at various interfaces in an explosive train. The train consists of an RP-2 detonator, $25 \mathrm{~mm}$ of $1 \mathrm{~g} / \mathrm{m}$ PETN MDF, five segments of HNS II MDF $(6.35,6.35,12.70,6.35$ and $6.35 \mathrm{~mm})$, and an acceptor pellet stack. The length of the acceptor stack varies from 2.54 to $10.16 \mathrm{~mm}$ in order that excess transit time can be measured by the cutback method. The segments of MDF are separated by $13 \mu \mathrm{m}$ air gaps to create the interfacial signals. There is no air gap, and therefore no interfacial signal between the final MDF segment and the pellet stack. The typical transit time for the final air gap-MDF segment combination is calculated from those measured from all the other gap-segment pairs. This average is then subtracted from the total time measured on each shot for the final air gap-MDF segment-pellet stack combination, giving the transit time for the pellet stack. 
Preliminary tests were conducted to determine the minimum size MDF to be used in part one of the sensitivity study, Results, which are given in Table II, indicate that the $1.52 \mathrm{~mm}$ OD MDF is probably the critical size for initiation of a $1.60 \mathrm{Mg} / \mathrm{m}^{3}$ acceptor pellet. It is not known which of the two MDF samples was used in this study.

MDF from each vendor was drawn to the four largest sizes in sufficient quantities for the test series. ${ }^{\alpha}$ Samples of each size including the original MDF were submitted for HE core analysis and the results are given in Table III. $b$

Original size MDF from each vendor was tested for its ability to sustain the detonation wave down the MDF train despite the $13 \mu \mathrm{m}$ air gaps. Results are presented in Table IV. In the first four shots E-B and ET MDF were tested with relatively low density acceptor pellets. Neither of the E-B shots, but both of the ET shots, failed due to the detonation not propagating from one segment to the next. On the following six shots the MDF segment ends were coated with fine PETN powder. In addition the acceptor pellet density was raised to $1.65 \mathrm{Mg} / \mathrm{m}^{3}$, the highest to be used in the sensitivity study. One ET shot failed because an MDF segment was not initiated. There was no failure due to an acceptor pellet not igniting. The failures for ET MDF are possibly due to the decreased sensitivity to initiation associated with the higher density core loading. Because of the small sample size, no assertion can be made as to the effect the PETN coating has upon the MDF segment transit time.

MDF data were obtained from the shots listed in Table IV: Results for each MDF are shown in Tables $V$ and VI. The excess transit time due to the air gap for the ET MDF is larger by a factor of four than that for the E-B MDF. This agrees with the failures for ET MDF listed in Table IV. The ET material has the higher detonation velocity indicating that the core density is higher, which is in accordance with the densities given in Table III.

The results obtained for the $1.65 \mathrm{Mg} / \mathrm{m}^{3} \mathrm{PX}-11$ acceptor pellets are given in Table VII. The detonation velocities are higher by about $5 \%$ than those obtained in prior work $(3,4)$ indicating some error in present work due to the limited number of shots. The excess transit time for acceptor pellets initiated by ET MDF is half that for pellets initiated by E-B MDF. This is probably due to the higher density core material of the ET MDF, which causes the detonation wave to attain a higher peak pressure.

Work on the project was suspended temporarily because of the failures of detonation propagation in the ET MDF train. In addition the failure rate will possibly increase as the MDF size is decreased. Previous work(4) has indicated that the shot loss rate is not improved by reducing

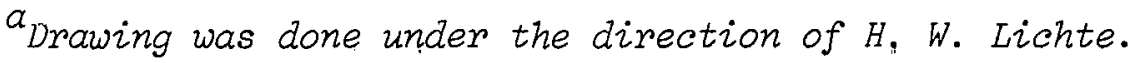

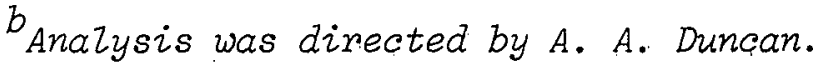


gap size from $25 \mu \mathrm{m}$ to $5 \mu \mathrm{m}$, because the decrease in failures due to non-propagation of the detonation wave is counterbalanced by a loss of some air gap signals.

An optoelectronics technique for measuring detonation wave arrival times at various interfaces in an explosive system is being investigated. Use of this timing method may allow the air gap size to be reduced essentially to zero, thus improving the shot loss rate.

\section{FUTURE WORK}

After the optoelectronic technique has been investigated, work upon the project will be commenced using the more promising timing technique. 
Table I. Properties of MDF Obtained in Pilot Drawing Operation ${ }^{\alpha}$

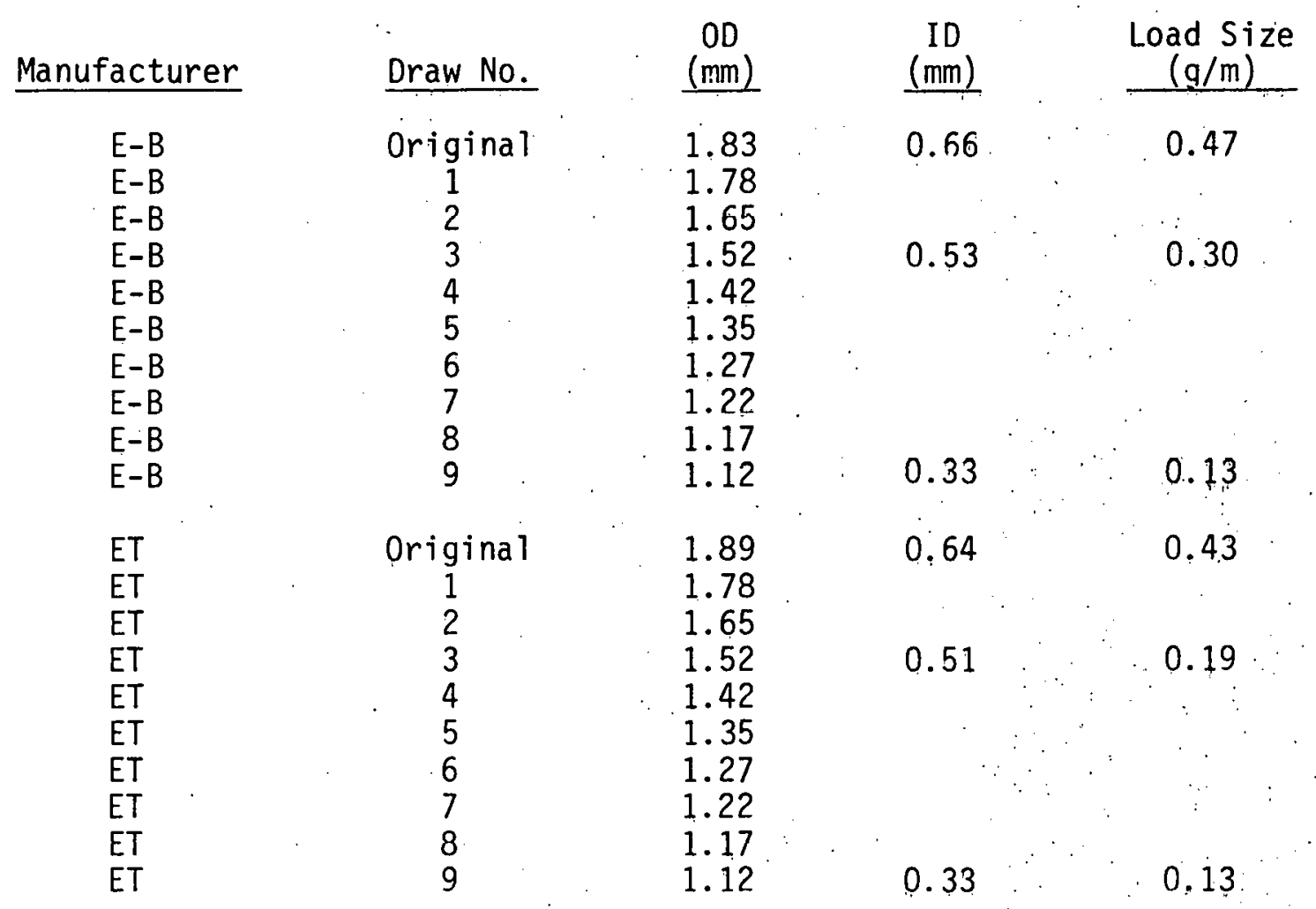

$a_{\text {Information obtained from } H \text {. W. Lichte }}$ 
Table II: : Results of Preliminary Study for the Initiability of the Pellets as a Function of MDF Size and Pellet Density

\begin{tabular}{|c|c|c|c|}
\hline Shot No: & $\begin{array}{l}\text { MDF OD } \\
(\mathrm{mm})\end{array}$ & $\begin{array}{c}\text { Pellet Density } \\
\left(\mathrm{Mg} / \mathrm{m}^{3}\right)\end{array}$ & Results \\
\hline $\begin{array}{l}1 \\
2 \\
3 \\
4 \\
5 \\
6 \\
7 \\
8 \\
9\end{array}$ & $\begin{array}{l}1.52 \\
1.52 \\
1.52 \\
1.52 \\
1.52 \\
1.52 \\
1.12 \\
1.12 \\
1.12\end{array}$ & $\begin{array}{r}1.6 \\
1.5 \\
1.6 \\
1.5 \\
1.5 \\
1.5 \\
1.5 \\
1.4 \\
1.4 \\
1.4\end{array}$ & $\begin{array}{l}\text { NO GO }{ }^{a} \\
\text { GO } \\
\text { NO GO } \\
\text { NO GO } \\
\text { GO } \\
\text { GO } \\
\text { BAD DETONATOR } \\
\text { NO GO } \\
\text { NO GO }\end{array}$ \\
\hline
\end{tabular}

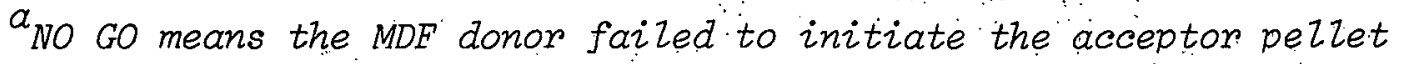


Table III. Properties of MDF Selected for Use $a^{a}$

\begin{tabular}{|c|c|c|c|c|}
\hline MDF Type & Sample No. & $\begin{array}{c}O D \\
(\mathrm{~mm}) \\
\end{array}$ & $\begin{array}{l}\text { HE Density } \\
\left(\mathrm{Mg} / \mathrm{m}^{3}\right)\end{array}$ & $\begin{array}{c}\text { Load Size } \\
(\mathrm{g} / \mathrm{m}) \\
\end{array}$ \\
\hline $\begin{array}{l}E-B \\
E-B \\
E-B \\
E-B \\
E-B \\
E-B\end{array}$ & $\begin{array}{ll} & 1 \\
. \quad & 2 \\
. & 3 \\
. & 4 \\
& 5 \\
6\end{array}$ & $\begin{array}{l}1.83 \\
1.83 \\
1.78 \\
1.65 \\
1.52 \\
1.42\end{array}$ & $\begin{array}{l}1.56 \\
1.57 \\
1.68 \\
1.57 \\
1.54 \\
1.55\end{array}$ & $\begin{array}{ll} & 0.55 \\
& 0.55 \\
& 0.65 \\
& 0.45 \\
\ldots & 0.38 \\
& 0.34\end{array}$ \\
\hline $\begin{array}{l}\text { ET } \\
\text { ET } \\
\text { ET } \\
\text { ET } \\
\text { ET } \\
\text { ET }\end{array}$ & $\begin{array}{r}7 \\
8 \\
9 \\
10 \\
11 \\
12\end{array}$ & $\begin{array}{l}1.89 \\
1.89 \\
1.78 \\
1.65 \\
1.52 \\
1.42\end{array}$ & $\begin{array}{r}- \\
1.64 \\
1.60 \\
1.59 \\
1.59 \\
1.58\end{array}$ & $\begin{array}{l}c \\
-c \\
0.58 \\
0.55 \\
0.43 \\
0.36 \\
0.33\end{array}$ \\
\hline
\end{tabular}

$a_{\text {Information obtained from } A \text {. A. Duncan }}$

$b_{\text {Results do not fit trend of other data }}$

${ }^{c}$ Somple destroyed by attempt to split lengthwise 
Table IV. Results of Initial Cutback Shots

\begin{tabular}{|c|c|c|c|c|c|}
\hline Shot No. & $\begin{array}{c}\text { MDF } \\
\text { Manufacturer } \\
\end{array}$ & $\begin{array}{l}\text { MDF OD } \\
(\mathrm{mm})^{a} \\
\end{array}$ & $\begin{array}{c}\text { PETN } \\
\text { Coating }^{b}\end{array}$ & $\begin{array}{c}\text { Pellet Density } \\
\left(\mathrm{Mg} / \mathrm{m}^{3}\right)^{-}\end{array}$ & Result \\
\hline $\begin{array}{l}1 \\
2 \\
3 \\
4\end{array}$ & $\begin{array}{l}\text { E-B } \\
\text { E-B } \\
\text { ET } \\
\text { ET }\end{array}$ & $\begin{array}{l}1.83 \\
1.83 \\
1.89 \\
1.89\end{array}$ & $\begin{array}{l}\text { NO } \\
\text { NO } \\
\text { NO } \\
\text { NO }\end{array}$ & $\begin{array}{l}1.39 \\
1.38 \\
1.32 \\
1.31\end{array}$ & $\begin{array}{l}\text { GO } \\
\text { GO } \\
\text { Failed } \\
\text { Failed }\end{array}$ \\
\hline $\begin{array}{r}5 \\
6 \\
7 \\
8 \\
9 \\
10\end{array}$ & $\begin{array}{l}E-B \\
E-B \\
E-B \\
E T \\
E T \\
E T\end{array}$ & $\begin{array}{l}1.83 \\
1.83 \\
1.83 \\
1.89 \\
1.89 \\
1.89\end{array}$ & $\begin{array}{l}\text { YES } \\
\text { YES } \\
\text { YES } \\
\text { YES } \\
\text { YES } \\
\text { YES }\end{array}$ & $\begin{array}{l}1.65 \\
1.65 \\
1.65 \\
1.65 \\
1.65 \\
1.65\end{array}$ & $\begin{array}{l}\text { GO } \\
\text { GO } \\
\text { GO } \\
\text { Failed } \\
\text { GO } \\
\text { GO }\end{array}$ \\
\hline
\end{tabular}

$a_{M D F}$ was "as received" from the manufacturer.

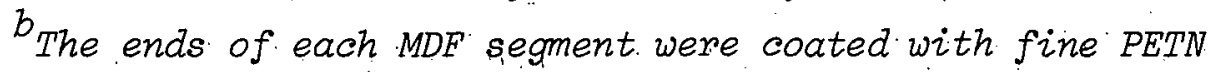

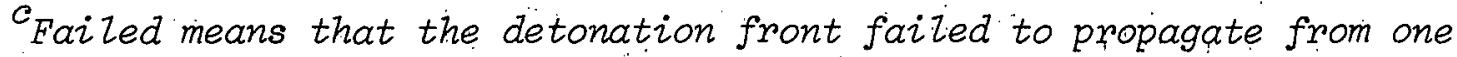
segment to the next. 
Table V. Results Obtained for the Original E-B MDF

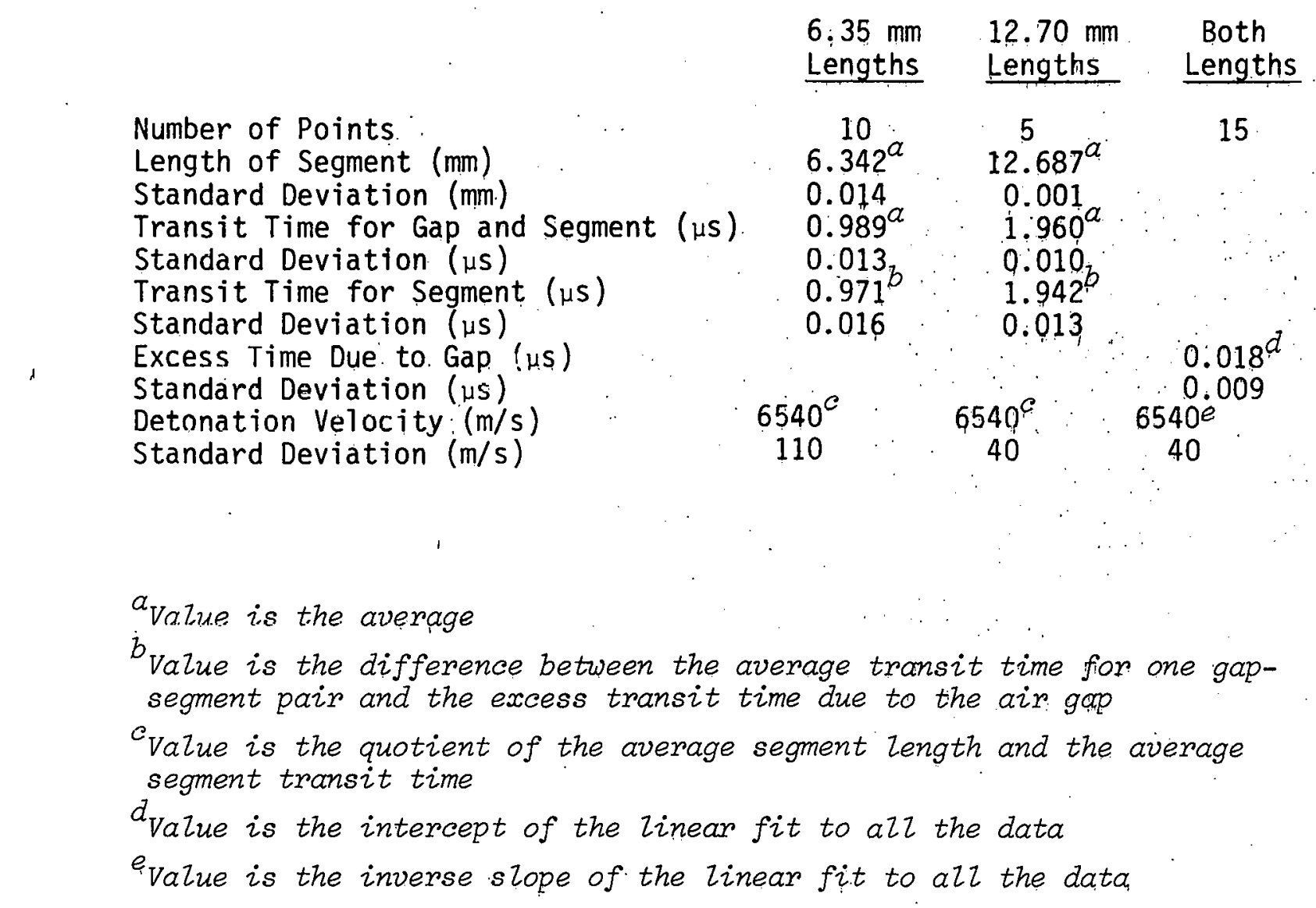


Table VI. Results Obtained for the Original ET MDF

\section{$6.35 \mathrm{~mm} \quad 12.70 \mathrm{~mm}$. Both Lengths Lengths Lengths}

Number of Points

Length of Segment ( $\mathrm{mm}$ )

Standard Deviation (mm)

Transit Time for Gap and Segment ( $\mu s$ )

Standard Deviation ( $\mu \mathrm{s}$ )

Transit Time for Segment (us)

Standard Deviation ( $\mu \mathrm{s}$ )

Excess Time Due to Gap ( $\mu \mathrm{s}$ )

Standard Deviation ( $\mu \mathrm{s}$ )

Detonation Velocity $(\mathrm{m} / \mathrm{s})$

Standard Deviation (m/s)
6

$6.341^{a} \cdot 12.630^{a}$

$0.013 \ldots .028$

$0.967^{a} \cdot 1.860^{a}$

$0.023 \quad 0.010$

$0.894^{b} \quad 1.787^{b}$

$0.030 \quad 0.022$

$0.073^{d}$

0.020

$7100^{c}$

240

$7110^{c}$

90.

$7110^{e}$

110

$a_{\text {Value is the average }}$

$b_{\text {Value }}$ is the difference between the average transit time for one gapsegment pair and the excess transit time due to the air gap.

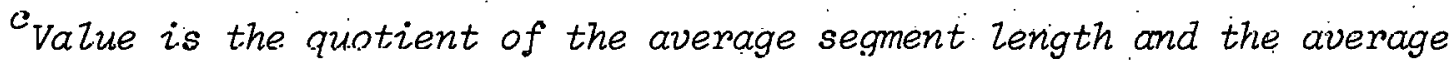
segment transit time

$d_{\text {Value }}$ is the intercept of the linear fit to all the data

$e_{\text {Value }}$ is the inverse slope of the linear fit to all the data 


\section{Table VII. Experimental Results for Pellets Initiated by (a) Original E-B MDF, (b) Original ET MDF and (c) Both E-B and ET MDF}

\begin{tabular}{|c|c|c|c|c|c|}
\hline $\begin{array}{l}\text { Density } \\
\left(\mathrm{Mg} / \mathrm{m}^{3}\right)\end{array}$ & $\begin{array}{l}\text { Standard } \\
\text { Deviation } \\
\left(\mathrm{Mg} / \mathrm{m}^{3}\right)\end{array}$ & $\begin{array}{c}\text { Excess Transit } \\
\text { Time } \\
\text { (ns) }\end{array}$ & $\begin{array}{l}\text { Standard } \\
\text { Deviation } \\
\text { (ns) }\end{array}$ & $\begin{array}{c}\text { Detonation } \\
\text { Velocity } \\
(\mathrm{m} / \mathrm{s}) \\
\end{array}$ & $\begin{array}{l}\text { Standard } \\
\text { Deviation } \\
\text { (m/s) }\end{array}$ \\
\hline 1.656 & 0.011 & 66 & 24 & 7350 & 230 \\
\hline 1.652 & 0.001 & 36 & $0^{\alpha}$ & 7290 & $0^{\alpha}$ \\
\hline 1.654 & 0.008 & 67 & 24 & 7451 & 221 \\
\hline
\end{tabular}

$a_{\text {Zero because the linear fit was done only on two datum points }}$ 


\section{REFERENCES}

1. T. W. Stul1, "Synthesis of High Purity Hexanitrostil̨bene," MHSMP-7537 (September 1975).

2. Bernard Hayes, "The Detonation Electric Effect," Journal of Applied Physics, Vol. 38, No. 2. (February 1967).

3. L. D. Hanes, "Initiation Sensitivity of HNS I by HNS II MDF,". MHSMP-76-5N (December 1975).

4. L. D. Hanes, "Comparison of Pantex High Purity HNS I to a Chemtronics HNS I for Their Sensitivity to Initiation by HNS II MDF." MHSMP-76-13 (April 1976). 